\title{
THE LIFE IN LAW OF GEORGE PATERSON BARTON QC
}

\section{Dame Sian Elias*}

This address was given by the Chief Justice of New Zealand, Dame Sian Elias, on the occasion of the special sitting of the High Court in Wellington to honour Dr George Barton QC on Wednesday 6 July 2011.

Thank you for coming to this special sitting of the High Court. It is convened to mark with respect, admiration and affection the life in law of George Barton.

To Ailsa, special thanks for agreeing to provide us this opportunity and for being here to share with us. It is lovely to have with Ailsa young George Barton, and the Registrar who conducts the Court today is Sarla Barton.

This occasion, in the historic courtroom George Barton knew so well, allows us to say things that should not be left unsaid at this time and to reflect on the way in which this extraordinary man has enriched our lives and the law he served so well.

I will first take the appearances of our Queen's Counsel.

In this gathering, I know there are very many who would be delighted to share their reflections upon the contribution made by George Barton to our profession and to the law. He was one of those special people that everyone counted as a friend and all of us have personal stories to tell of him and reflections on what he meant to us. Although of necessity we have had to limit the number of speakers, I am sure that the representative appreciations in the formal sitting will roll on further exchanges outside the courtroom.

As Chief Justice, I am able to claim the privilege of speaking myself. I intend to exercise that right shortly and before calling upon members of the profession to speak. Before doing so, I think it is fitting to defer first to Sir Ivor Richardson. He is able to provide an unparalleled perspective and appreciation of this man we gather to remember and to honour.

* The Rt Honourable Dame Sian Elias, Chief Justice of New Zealand. 
Although an Auckland practitioner, I first met George on some early forays into the Court of Appeal in the early 1970s and at Law Society conferences in that decade. George was a great supporter of women in the law at a time when many were not. He made a point of making me welcome and taking an interest in my career, as he did with so many practitioners. He was the exemplar of the school-lawyer. Always breaking off in mid-conversation to look something up, particularly a scrap of legal history. Always generous with his time, advice, and encouragement. The law he lived was compelling and fun. He reminded all of us why we had wanted to be lawyers and of what can be achieved through law.

The rule of law is fragile. It depends especially upon an independent and fearless profession. As Sir Owen Dixon once acknowledged, the profession is more important to the rule of law even than an independent and fearless judiciary. ${ }^{1}$ Justice Douglas of the United States Supreme Court said truly that civil liberties survive only "when the Bar is alert to defend them - when the Bar is courageous, when the Bar is mindful of its responsibilities". ${ }^{2}$

These qualities of vigilance, courage, and responsibility need to be demonstrated in actual cases by individual lawyers, even when it is not popular to stand up and speak for the rule of law especially when others are silent. In our times, no one has exemplified in our legal system these qualities more than George Barton. That is why it is right that we come together to honour him, to express our great gratitude that we lived with such a giant - and perhaps to be encouraged in our own turn to hold fast to the values he lived by.

There are so many illustrations each of us could give about George Barton. I want to give three sketches that occurred to me in thinking back over my association with him. They would not feature in a list of George's major achievements and they are random personal associations rather than an appreciation of the whole man. But they are picture images I have of George - his erect bearing, his determination to do what had to be done, his personal courage, and his kindness.

The first concerns the New Zealand Māori Council fishing litigation. The Government was pressing ahead with creating property rights in fish species, despite a Waitangi Tribunal recommendation that the process be stopped while Māori fishing interests were assessed. The Fisheries Act (under which the quota process had proceeded) continued to contain, as it had since the 1870 s, ${ }^{3}$ a provision saying: "Nothing in this Act shall affect any Maori fishing rights". ${ }^{4}$ No one knew what it meant. I thought we might as well put it to the test in litigation, because otherwise all

1 Owen Dixon Jesting Pilate (The Law Book Company Ltd, Melbourne, 1965) at 245-246.

2 William O Douglas in an address to the Edmonton Bar Association (The New York Times, 16 August 1953) as cited in "The Independence of the Bar" (1953) 13 Lawyers Guild Review 158 at 159.

3 See Fish Protection Act 1877, s 8.

4 Fisheries Act 1983, s 88(2). 
the fish would be gone. Senior counsel, David Baragwanath, was more cautious and sensibly thought we should try to persuade the Crown to pause and discuss. Flying back to Auckland after we had been sent packing we decided that, indeed, we had nothing to lose. That afternoon we faxed some cobbled-together papers down to Megan Richardson, then a researcher at the Law Commission. She had to tap on the window of the Registry in this building because it was after the Registry had closed, but she managed to get the papers accepted. We needed counsel to appear on them; I rang George Barton. He was not in, but his redoubtable secretary, Beverly Davey, said she would get hold of him. By 6 pm he had obtained from Justice Greig the interim injunction that led directly, and I think without troubling the courts further, to the huge fisheries settlement. It was an audacious and decisive blow. No one was more qualified than George Barton to appear for Māori, having represented Māori interests over many years including as junior counsel to Spratt in the great Wanganui River litigation. ${ }^{5}$ Ms Davey was always very discreet and she had not told me where George was when I rang. It was not till later that I found out that he had been extracted from his barber's chair to go directly to the Court. He got the call, he knew it was important, and he went immediately, without question.

The second image I have of George is in this very courtroom. I was junior counsel to Ted Thomas in Finnigan and Recordon, the Tour case. Sir Maurice Casey had granted an interim injunction on the Saturday preventing the All Blacks leaving for South Africa, to eruptions from the gallery up there. ${ }^{6}$ We were reconvened on the Monday to continue the litigation. There had of course been a great to-do about the injunction. Justice Casey had been the subject of a number of intemperate attacks on the radio and in the press. Before the case was called, a lone figure stood to claim attention of the Court: George Barton wigged and gowned, bowed profoundly to the Judge, to signify his respect. That image of an upright and fearless figure, doing what he knew to be right, is something I think of often, and whenever I enter this beautiful room.

The last image I want to share is again of a lonely stand, this time on an international stage. It was a meeting of the American Law Institute (ALI) in San Francisco in 2003. It was a gathering of the great and the good in the American legal world, and further afield. We were working on the ALI model sentencing code, a work many years in the preparation, only this year completed. George Barton went to the microphone and urged the Institute to show leadership in setting its face against capital punishment. The ALI is very sensitive about its reputation for steering clear of political controversy. The attitude to the topic was cool. Raising it was seen by many to be a little impolite. The contribution was a brave one, especially made in a New Zealand accent. But it was the right thing for someone of conviction to urge a great organisation to show leadership. It made me, as a

5 In re the Bed of the Wanganui River [1962] NZLR 600 (CA).

6 Finnigan v New Zealand Rugby Football Union (No 2) [1985] 2 NZLR 181 (HC). 
New Zealander, very proud. I am sure that George himself must have been well satisfied when a year or so later the Institute did indeed come out against capital punishment.

George Paterson Barton was a great man. He was an example to our profession and he enriched our lives. 